\title{
Molecular Genetics of Neuronal Ceroid Lipofuscinoses
}

\author{
IRMA JÄRVELÄ, JOUNI VESA, PIRKKO SANTAVUORI, ELINA HELLSTEN, AND \\ LEENA PELTONEN \\ National Public Health Institute, Department of Human Molecular Genetics [I.J., J.V., E.H., L.P.] and \\ Children's Hospital [P.S.], University of Helsinki, Helsinki, Finland
}

\begin{abstract}
This overview describes recent advances in molecular biology of neuronal ceroid lipofuscinoses (CLN). Despite intensive research during last 20 years, the basic defects of these autosomal recessive-progressive encephalopathies of childhood remain unknown. Consequently, no specific cure is available. Methods of positional cloning (reverse genetics) starting from random linkage approach have been applied to search for gene defects in the infantile and juvenile forms of the disease. The results of this random search for disease loci have for the first time revealed molecular heterogeneity of CLN diseases. The gene defect causing the infantile form has been assigned to $1 \mathrm{p} 32$ in the Finnish family material, whereas the disease locus of the juvenile form has been localized to $16 \mathrm{p} 12$ in European and Canadian families. Finally, the gene defect causing the late infantile form has been excluded from both $1 \mathrm{p} 32$ and 16p12 chromosomal regions, referring to a third, still unknown locus causing CLN disease. Consequently, reliable prenatal and carrier diagnostics have now become possible in families with the infantile and juvenile forms of the disease, and DNA-based prenatal diagnostics have been successfully applied in the infantile form. Most importantly, the assignment of gene loci has brought these fatal brain diseases within the reach of molecular cloning strategies that eventually will result in revealing both the infantile and juvenile CLN genes and in identifying corresponding gene products. (Pediatr Res 32: 645-648, 1992)
\end{abstract}

\section{Abbreviations}

CLN, ceroid lipofuscinosis, neuronal

CLN1, infantile neuronal ceroid lipofuscinosis

CLN2, late infantile neuronal ceroid lipofuscinosis

CLN3, juvenile neuronal ceroid lipofuscinosis

MRI, magnetic resonance imaging

CLN is one of the most common progressive encephalopathies in Western countries $(1,2)$. The main features of this disease are failure of psychomotor development, impaired vision, seizures, familial occurrence, and premature death. The term neuronal ceroid lipofuscinosis was introduced in 1969 by Zeman and Dyken (3) to distinguish these disorders from other types of amaurotic family idiocy. Despite intensive research during the last 20 years, the enzyme defects of this group of neurometabolic diseases still remain unknown. The accumulated storage sub-

Received May 14, 1992; accepted July 30, 1992.

Correspondence and reprint requests: Prof. Leena Peltonen, National Public Health Institute, Department of Human Molecular Genetics, Mannerheimintie 166, 0300 Helsinki, Finland.

This project has been funded by the Academy of Finland and Rinnekoti Research Foundation Espoo, Finland. stance common to the different forms of CLN resembles lipopigment, showing autofluorescence and acid phosphatase activity and intense staining with the Sudan black B and periodic acid Schiff methods. These properties are similar to those of lipofuscin and ceroid. Lipofuscin is a compound known to accumulate in most cell types with age. It is caused by nonspecific peroxidation of polyunsaturated fatty acids present in complex lipids of different membranes. Ceroid is also a compound with some characteristics of lipofuscin, but it is formed mainly in certain experimental and pathologic conditions (4). These morphologic findings are highly nonspecific in nature, and, consequently, numerous theories (5-8) are put forward to explain the pathology of CLN diseases. However, no fruitful clues to elucidate the metabolic basis of these brain diseases have been suggested.

\section{CLASSIFICATION}

CLN in childhood are divided into three principal clinical groups: infantile (INCL, Santavuori disease, CLN1, McKusick 256730), late infantile (LINCL, Jansky-Bielschowsky disease, early-onset Batten's disease, CLN2, McKusick 204500), and juvenile (JNCL, late-onset Batten's disease, Spielmeyer-SjögrenVogt disease, CLN3, McKusick 204200) (2, 9). A fourth type, adult CLN (Kufs' disease, CLN4, McKusick 204300), is typically a rare form in adults and will not be considered further here. The classification of CLN is based on the age of onset, clinical course of the disease, neurologic, ophthalmologic, neurophysiologic, and ultrastructural findings (Table 1) (2). All childhood forms are inherited as an autosomal recessive trait. About $10 \%$ of all CLN patients represent variant or atypical forms, which are difficult to classify into the three main childhood groups (1014). Repeated clinical examinations of the patients and sufficient follow-up times provide diagnostic accuracy in uncertain cases. These patients usually have features common to both the late infantile and juvenile forms and are classified as the late infantile group, which, consequently, can actually represent several disease entities.

\section{DIAGNOSTIC CRITERIA AND DIFFERENTIAL DIAGNOSTICS}

CLN1. The infantile form is the earliest and most severe form of CLN. The first symptoms appear at 8 to 20 mo of age, and in the follow-up the disease is characterized by rapid psychomotor deterioration, muscular hypotonia, microcephaly, ataxia, choreoathetosis, myoclonic jerks, and knitting hyperkinesia. Partial and generalized seizures and, occasionally, Lennox-like syndrome are seen. Anxiety and hyperexcitability are apparent in most patients at the age of 1.5 to $2.5 \mathrm{y}$. Visual symptoms, slow or absent pupillary response, optic atrophy, and macular and retinal degeneration without pigment aggregations are diagnosed by the age of $2 \mathrm{y}$. The most characteristic finding of CLN1 is isoelectric EEG at the age of $3 \mathrm{y}$, the status of the children resembling brain death $(2,15)$. Recent studies have shown that 
Table 1. Summary of characteristics of CLN in childhood*

\begin{tabular}{llll}
\hline & \multicolumn{1}{c}{ CLN1 } & \multicolumn{1}{c}{ CLN2 } & CLN3 \\
\hline Age of onset & $8-18 \mathrm{mo}$ & $2-4 \mathrm{y}$ & $4-8 \mathrm{y}$ \\
Age at death & $8-14 \mathrm{y}$ & $6-15 \mathrm{y}$ & $13-40 \mathrm{y}$ \\
Retinal pigment aggregations & Negative & Rare & Positive \\
EEG & Isoelectric by $3 \mathrm{y}$ & Spikes inducible by low & Unspecific \\
& & photic stimulation & Abolished \\
ERG & Abolished & Abolished & Early abnormal \\
VEP & Abolished by 2-4 y & Early high & Positive \\
Vacuolated lymphocytes & Negative & Negative & Fingerprint \\
Storage particles & Granular osmio- & Curvilinear profiles & profiles \\
Mitochondrial ATP-synthase sub- & philic deposits & No change & Increased \\
$\quad$ unit-C & & & Increased \\
Chromosomal assignment & $1 \mathrm{p} 32$ & Not known; excluded at & $16 \mathrm{p} 12$
\end{tabular}

*ERG, electroretinogram; VEP, visual-evoked potential.

MRI intensity changes appear early, even before clinical signs (16). The ultrastructural picture of the tissue usually performed as a suction biopsy from the rectum shows granular osmiophilic deposits (17). The mean age of death is about $10 \mathrm{y}$.

CLN1 is enriched in the population of Finland, the incidence being 1 in 20000 . A total of 124 CLN1 patients have been described in the genetically isolated Finnish population of 5 million inhabitants during last $20 \mathrm{y}$, whereas about 100 cases have been reported from other populations.

Rett's syndrome is the most important differential diagnostic disease, especially in girls at the age of 1.5-2 y because of the knitting hyperkinesia that is typical in the children suffering from this disorder (18). Early autism, acute cerebellar ataxia, encephalitis, epilepsies, and prenatal disorders are also important for differential diagnostics.

$C L N 2$. The first symptoms of the classic late infantile form start after $2 \mathrm{y}$ of age with epilepsy and dementia and also with retarded speech development. Ataxia and myoclonia occur soon afterwards. Typically, visual failure appears after the neurologic symptoms. Neurophysiologic studies have proved to be especially important in this form because of typical spikes induced by low photic stimulation in EEG and high-amplitude curve found in the visual-evoked potential test. The ultrastructural investigation of different tissues of these patients reveal curvilinear profiles of unknown origin. Death occurs between 6 and 15 y of age. Incidence estimates are hard to find, although this form is relatively common in Great Britain and North America $(2,19)$.

Most of the atypical or variant forms of CLN resemble the classic CLN2. One of them is the cluster of 16 families with the variant CLN2 in Finland $(20,21)$. Another similar group has been found in Great Britain (10) and a third in Newfoundland (14). The clinical picture and neurophysiologic findings of these forms resemble the classic CLN2, but the ultrastructural investigation reveals fingerprint profiles, storage of the unknown material accumulated in different tissues, in some cases resembling the juvenile form (20). MRI intensity changes appear early in the Finnish variant cases (22). The age at onset, as well as the age at death, is somewhat later than in the classic form (2).

$C L N 3$. The juvenile form, or Batten's disease, is the most common type of CLN in the world, with the highest incidence in North European countries. The first clinical symptom is visual failure starting at 4-7 y. After $10 \mathrm{y}$ of age, mental retardation, epilepsy and parkinsonism-like motor clumsiness occur. Typical diagnostic signs are retinal pigment aggregations and vacuolated lymphocytes in peripheral blood. Fingerprint profiles are found in ultrastructural investigation. Life expectancy is $13-40$ y (2).

CLN3 is the form of CLN diseases in which a biochemical finding with some specificity has recently been described. From tissue extracts, excessive amounts of mitochondrial ATP-synthase subunit-C have been isolated. However, because similar findings have been reported from tissues of patients manifesting classic CLN2, this perhaps represents a phenomenon secondary to the primary gene defect (8).

In computed tomography and MRI, brain atrophy correlates with age and is pronounced early in CLN1 $(22,23)$. With repeated clinical examinations and follow-up, the progressive nature of all CLN diseases is revealed and the diagnosis successfully found (Table 1).

\section{ASSIGNMENT OF CLN1 AND CLN3}

The positional cloning strategy was applied to map the CLN diseases because biochemical or histochemical studies had revealed no relevant candidate genes. No chromosomal abnormality has been reported in these patients that could have served as a starting point for mapping the gene defect.

Recent developments in mapping the human genome with highly polymorphic markers have created tools to map any gene causing a human disease-even rare recessive phenotypesprovided relevant family material is available (24).

Using linkage analyses of the random markers assigned to individual chromosomes, the locus for CLN3 (Batten's disease) was successfully assigned to the short arm of chromosome 16 $(25-27)$ in 58 European and Canadian families. Soon thereafter. the gene causing CLN1 was mapped to chromosome $1 \mathrm{p} 32$ in 40 Finnish nuclear families (28) (Fig. 1). When markers demonstrating linkage to CLN3 and CLN1 were analyzed in 26 classic CLN2 families, definitive exclusion of this locus from these chromosomal regions was established. This finding refers to a third still-unidentified locus in the human genome for CLN diseases, which would be responsible for CLN2 (21, Williams R, Vesa J, McKay T, Mitchison H, Järvelä I, Thompson A, Callen D, Sutherland G, Luna-Battadano D, Stallings R, Peltonen L, Gardiner RM, unpublished observations). Currently, CLN1 is assigned to a chromosomal region covering about 5 centimorgans between the markers D1S57 and D1S62 at 1p32. CLN3 has been assigned to an approximate 2-centimorgan region between the markers D16S67 and D16S148 (27). These distances are still considerable at the molecular level, corresponding to about 5 million (CLN1) and 2 million (CLN3) bp of the DNA strands, respectively. However, the disease loci are now well defined in the human genome, with border-lining markers facilitating the use of molecular cloning strategies, allowing identification of the corresponding genes. The observed linkage disequilibrium found with some markers in CLN chromosomes versus non-CLN chromosomes actually suggests that the distance to the disease gene is shorter than the one predicted from genetic distance between the markers (21).

\section{HETEROGENEITY OF CLN DISEASES}

Well-established diagnostic criteria for three main childhood forms have generated reliable clinical diagnostics in the hands of 


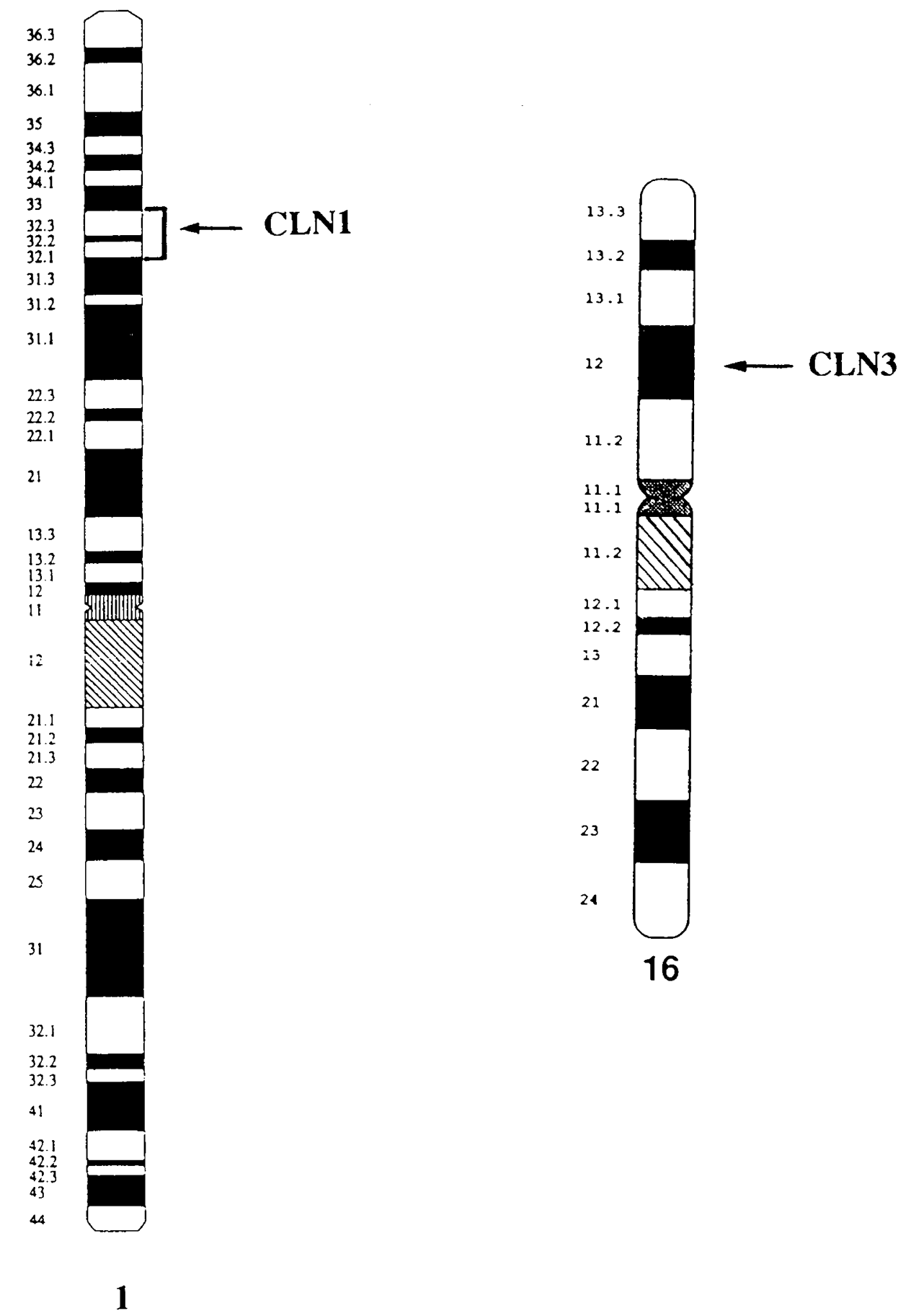

Fig. 1. Chromosomal localization of the infantile (CLN1) and juvenile (CLN3) forms of CLN.

specialists and actually formed a solid base for mapping of the disease loci involved. False phenocopies and locus heterogeneity in small family materials could have been fatal for the linkage approach. Due to the enrichment of the rare CLN1 gene in the isolated Finnish population, the mapping of this gene was possible only in Finland and also supported the hypothesis of one locus behind this form.

Strong linkage disequilibrium has been found with several polymorphic markers in the vicinity of L-MYC at $1 \mathrm{p} 32$ in CLN1 chromosomes of the Finnish patients (21). With one multiallelic marker, $95 \%$ of the affected CLN1 chromosomes and $87 \%$ of the diseased children represent the same homozygote haplotype, whereas all the non-Finnish patients have different allele combinations. This suggests that one mutation causes CLN1 in Finland due to founder effect. The situation is highly analogous to the situation reported in the case of a lysosomal accumulation disease, aspartylglucosaminuria, also enriched in this isolated population, as one mutation is found to cause $98 \%$ of the cases in Finland opposed to the spectrum of different mutations found in patients from other populations (29).

\section{PRENATAL AND CARRIER DIAGNOSTICS}

Prenatal and carrier diagnostics have been required especially by CLN1 families after one affected child was born in the family. In such severe disorders with a high risk of recurrence $(25 \%)$, reliable prenatal diagnostics can help the families planning additional pregnancies. Fifteen pregnancies at risk for CLN1 have so far been analyzed in our laboratory using DNA markers linked to CLN1, and the results have been compared with the electron 
Table 2. Summary of DNA-based prenatal and carrier diagnoses of CLN1*

\begin{tabular}{lccc}
\hline $\begin{array}{c}\text { No. of } \\
\text { cases }\end{array}$ & $\begin{array}{c}\text { Risk of being } \\
\text { affected }(\%)\end{array}$ & $\begin{array}{c}\text { Risk of being } \\
\text { carrier }(\%)\end{array}$ & $\begin{array}{c}\text { Probability of } \\
\text { being healthy } \\
(\%)\end{array}$ \\
\hline 2 & 100 & 0 & 0 \\
1 & 97 & 3 & 0 \\
1 & 97 & 2 & 1 \\
1 & 96 & 4 & 0 \\
5 & 0 & 98 & 2 \\
3 & 2 & 97 & 1 \\
1 & 1 & 97 & 2 \\
3 & 2 & 96 & 2 \\
1 & 0 & 91 & 9 \\
3 & 0 & 4 & 96 \\
3 & 0 & 3 & 97 \\
1 & 0 & 2 & 98 \\
Total & 5 & 13 & 7 \\
\hline
\end{tabular}

* The probabilities of each individual being healthy, carrier, or affected have been calculated by MLINK option of LCP-package (31). A risk of $1 \%$ has been accepted between the disease locus and the three markers linked to CLN1.

microscopic investigation of chorionic villi of the same pregnancies (30) (Table 2). The results were concordant in all cases. The experience is more limited in CLN3; only one DNA-based prenatal diagnosis has been carried out. The fetus was predicted to be a carrier, but the pregnancy was aborted spontaneously because of intrauterine infection. DNA analyses have also made possible carrier status determination, and this can be offered to the family members as well.

Localization of genes for two types of CLN to different chromosomes is a major advance in resolving the genetic defect in CLN. These results serve as a prelude to the ultimate isolation and characterization of the genetic defect behind these devastating brain diseases.

\section{REFERENCES}

1. Rider JA, Rider DL 1988 Batten disease: past, present and future. Am J Med Genet (suppl) 5:21-26

2. Santavuori P 1988 Neuronal ceroid lipofuscinoses in childhood. Brain Dev 10 : $80-83$

3. Zeman W, Dyken P 1969 Neuronal ceroid-lipofuscinosis (Batten's disease): relationship to amaurotic familial idiocy? Pediatrics 44:570-583

4. Wolfe LS, Ivy G, Witkop CJ 1987 Dolichols, lysosomal membrane turnover and relationships to the accumulation of ceroid and lipofuscin in inherited diseases, Alzheimer's disease and aging. Chem Scr 27:79-84

5. Zeman W, Donahue S, Dyken P, Green J 1970 The neuronal ceroid-lipofuscinoses (Batten-Vogt syndrome). In: Vinken PJ, Bruyn GW (eds) Handbook of Clinical Neurology, Vol X. North-Holland Publishing Co., Amsterdam, pp 588-679

6. Svennerholm L, Hagberg B, Haltia M, Sourander P, Vanier MT 1975 Polyunsaturated fatty acid lipidosis. II. Lipid biochemical studies. Acta Paediatr Scand 64:489-496

7. Hall NA, Patrick AD 1985 Dolichol and phosphorylated dolichol content of tissues in ceroid-lipofuscinosis. J Inherited Metab Dis 8:178-183
8. Fearnley IM, Walker JE, Martinus RD, Jolly RD, Kirkland KB, Shaw GJ, Palmer DN 1990 The sequence of the major orptein stored in ovine ceroid lipofuscinosis is identical with that of the dicyclohexylcarbodi-imide-reactive proteolipid of mitochondrial ATP synthase. Biochem J 268:751-758

9. McKusick VA 1990 Mendelian Inheritance in Man, 9th Ed. Johns Hopkins University Press, Baltimore

10. Lake BD, Cavanagh NPC 1978 Early juvenile Batten's disease: a recognizable subgroup distinct from other forms of Batten's disease. J Neurol Sci 36: 265-271

11. Libert J, Martin JJ, Ceuterick C 1982 Protracted and atypical forms of ceroidlipofuscinosis. In: Armstrong D, Koppang N, Rider A (eds) Ceroid-lipofuscinosis (Batten's disease). Elsevier Biomedical Press, Amsterdam, pp 45-59

12. Santavuori P, Haltia M, Rapola J, Raitta C 1982 A variant Jansky-Bielschowsky disease. Neuropediatrics 13:135-141

13. Kimura S, Goebel H 1987 Electron microscopic studies on skin and lymphocytes in early juvenile neuronal ceroid-lipofuscinosis. Brain Dev 9:576-580

14. Andermann E, Jacob JC, Andermann F, Carpenter S, Wolfe L, Berkovic S 1988 The Newfoundlander aggregate of neuronal ceroid lipofuscinosis. Am J Med Genet (suppl) 5:111-116

15. Santavuori P, Haltia M, Rapola J 1974 Infantile type of so-called neuronal ceroid lipofuscinosis. Dev Med Child Neurol 16:644-653

16. Santavuori $P$, Vanhanen $S-L$, Sainio $K$, Nieminen $M$, Autti $T$, Launes $J$ Raininko R 1991 New aspects in the diagnosis of neuronal ceroid lipofuscinoses. Brain Dysfunct (in press)

17. Rapola J, Santavuori P, Savilahti E 1985 Suction biopsy of rectal mucosa in the diagnosis of infantile type of neuronal ceroid lipofuscinosis. Hum Pathol 15:352-360

18. Hagberg B 1989 Rett syndrome: clinical peculiarities, diagnostic approach, and possible cause. Pediatr Neurol 5:75-83

19. Warburg M 1982 The natural history of Jansky-Bielschowsky's and Batten's diseases. In: Armstrong D, Koppang N, Rider A (eds) Ceroid-lipofuscinosis (Batten's disease). Elsevier Biomedical Press, Amsterdam, pp 35-44

20. Santavuori P, Rapola J, Nuutila A, Raininko R, Lappi M, Launes J, Herva R, Sainio K 1991 The spectrum of Jansky-Bielschowsky disease. Neuropediatrics 22:92-96

21. Järvelä I 1991 Infantile neuronal ceroid lipofuscinosis (CLN1): linkage disequilibrium in the Finnish population and evidence that variant late infantile form (variant CLN2) represents a non-allelic locus. Genomics 10:333-337

22. Raininko R, Santavuori P, Heiskala H, Sainio K, Palo J 1990 Neuroradiological findings in neuronal ceroid lipofuscinosis. Neuropediatrics 21:95-101

23. Santavuori P, Raininko R, Vanhanen S-L, Launes J, Sainio K 1992 MRI of the brain, EEG sleep spindles and SPECT in the early diagnosis of infantile neuronal ceroid lipofuscinosis. Dev Med Child Neurol 34:61-65

24. Stephens JC, Cavanaugh ML, Gradie MI, Mador ML, Kidd KK 1990 Mapping the human genome: current status. Science 250:237-244

25. Eiberg H, Gardiner RM, Mohr J 1989 Batten disease (Spielmeyer-Sjögren disease) and haptoglobin (HP): indication of linkage and assignment to chromosome 16. Clin Genet 36:217-218

26. Gardiner RM, Sandford A, Deadman M, Poulton J, Cookson W, Reeders S, Jokiaho I, Peltonen L 1990 Batten disease (Spielmeyer-Vogt disease, juvenile onset neuronal ceroid lipofuscinosis) gene (CLN3) maps to human chromosome 16. Genomics 8:387-390

27. Callen DF, Baker E, Lane S, Nanacarrow J, Thompson A, Whitmore SA, MacLennan DH, Berger R, Cherif D, Jarvela I, Peltonen L, Sutherland GR, Gardiner RM 1991 Regional mapping of the Batten disease locus (CLN3) to human chromosome 16p12. Am J Hum Genet 49:1372-1377

28. Järvelä I, Schleutker J, Haataja L, Santavuori P, Puhakka L, Manninen T, Palotie A, Sandkuijl LA, Renlund M, White R, Aula P, Peltonen L 1991 Infantile form of neuronal ceroid lipofuscinosis (CLN1) maps to the short arm of chromosome 1. Genomics 9:170-173

29. Ikonen E, Aula P, Grön K, Tollersrud O, Halila R, Manninen T, Syvänen AC, Peltonen L 1991 Spectrum of mutations in aspartylglucosaminuria. Proc Natl Acad Sci USA 88:11222-11226

30. Järvelä I, Rapola J, Peltonen L, Puhakka L, Vesa J, Ämmälä P, Salonen R, Ryynänen M, Haring P, Mustonen A, Santavuori P 1991 DNA-based prenatal diagnosis of the infantile form of neuronal ceroid lipofuscinosis (INCL). Prenat Diagn 11:323-328

31. Lathrop GM, Lalouel JM, Julier C, Ott J 1984 Strategies for multilocus linkage analysis in humans. Proc Natl Acad Sci USA 81:3433-3446 